\title{
Path Analysis on Factors Affecting the Quality of Life in Patients with Type 2 Diabetes Mellitus in Surakarta, Central Java
}

\author{
Devi Marlina1), Didik Gunawan Tamtomo), RB. Soemanto3) \\ 1)Masters Program in Public Health, Universitas Sebelas Maret \\ 2)Masters Program in Family Medicine, Universitas Sebelas Maret \\ 3)Faculty of Social and Political Sciences, Universitas Sebelas Maret
}

\section{ABSTRACT}

Background: Diabetes mellitus is a chronic disease that cannot be cured entirely, which greatly affects the quality of life. People with diabetes mellitus will experience a negative impact on the quality of life. This is because the patient experiences changes in his life. Measuring the quality of life in diabetic patients is very important, considering that diabetes mellitus sufferers are increasing every year. The purpose of this study was to analyze the factors that affect the quality of life in patients with type $2 \mathrm{DM}$.

Subjects and Method: This was a crosssectional study conducted at Dr. Moewardi Hospital, Central Java, from February to March 2020. A sample of 120 patients with type $2 \mathrm{DM}$ aged $>18$ years were selected by simple random sampling. The dependent variable was the quality of life. The independent variables were self-care, family support, peer support, length of disease, body mass index, and education. The data were collected by questionnaire and data analysis using path analysis with Stata 13 was used to collect data.

Results: Good quality of life in patient with type 2 DM improved with good self-care $(b=2.66$;
95\% CI $=0.38$ to $4.94 ; \mathrm{p}=0.022)$, strong family support $(\mathrm{b}=3.07 ; 95 \% \mathrm{CI}=1.09$ to $5.05 ; \mathrm{p}=$ o.002), strong peer support $(\mathrm{b}=3.43 ; 95 \% \mathrm{CI}=$ 1.14 to $5.72 ; p=0.003)$, time period of diagnosis time $<6$ years $(b=-2.90 ; 95 \% \mathrm{CI}=-5.00$ to -0.78 ; $\mathrm{p}=0.007)$, normal body mass index $(\mathrm{b}=-2.53$; 95\% CI $=-4.57$ to $-0.50 ; \mathrm{p}=0.014)$, and education $\geq$ senior high school $(b=2.46 ; 95 \% \mathrm{CI}=0.72$ to 4.21; $\mathrm{p}=0.006$ ).

Conclusion: Good quality of life in patients with type 2 DM increases with good self-care, strong family support, strong peer support, time period of diagnosis $<6$ years, normal body mass index, and education level $\geq$ senior high school.

Keywords: quality of life, type 2 diabetes mellitus

\section{Correspondence:}

Devi Marlina. Masters Program in Public Health, Universitas Sebelas Maret. Jl. Ir. Sutami 36A, Surakarta 57126, Central Java. Email: devimarlinaaa94@gmail.com. Mobile: +6281340983044.

Cite this as:

Marlina D, Tamtomo DG, Soemanto RB (2020). Path Analysis on Factors Affecting the Quality of Life in Patients with Type 2 Diabetes Mellitus in Surakarta, Central Java. J Epidemiol Public Health. 05(02): 227-236. https://doi.org/10.26911/jepublichealth.2020.05.02.10.

cc (F)(2) Journal of Epidemiology and Public Health is licensed under a Creative Commons cc) Attribution-Non Commercial-Share Alike 4.0 International License.

\section{BACKGROUND}

Diabetes mellitus (DM) is a major public health problem worldwide. According to data from the International Diabetes Federation in 2017 , Indonesia is the sixth country with the highest number of people with diabetes with 10.3 million sufferers after China, India, the United States, Brazil, and Mexico (IDF, 2017). DM is a metabolic disorder caused by the body's inability to respond to insulin, increasing blood sugar levels (Ministry of Health, 2013).

The prevalence of type II diabetes mellitus is more common than type I 
diabetes worldwide (IDF, 2017). According to data from the Surakarta Health Office, the city of Surakarta has a prevalence of type II diabetes mellitus, which has increased in the last five years. The increase in type II diabetes mellitus, from 5,223 cases in 2016, reached 6,579 cases in 2017 (Dinkes Surakarta, 2017).

Type II DM poses a high risk to public health and threatens the health care system. The effect of exposure to type II DM shows an increase in the occurrence of severe complications that lead to a decrease in the quality of life of a person (Gillani et al., 2018). DM patients need to measure the quality of life to see the achievement of good diabetes treatment care.

The factor that is related to the quality of life of patients with diabetes mellitus is dietary compliance. A study conducted by Lou et al. (2014) showed a correlation between sleep quality and quality of life for patients with type 2 DM. Poor sleep quality tends to cause anxiety and depression symptoms higher in type $2 \mathrm{DM}$ patients (Lou et al., 2014).

Previous studies have also reported that other factors such as age, treatment satisfaction, demographic characteristics, and the number of diabetes drugs have an influence on the quality of life in patients with diabetes mellitus (Gillani et al., 2018). The factor that encourages the need to measure the quality of life of patients with type $2 \mathrm{DM}$, namely the prevalence of diabetes mellitus continues to increase in Indonesia and worldwide. So far, there have been many studies that have raised the issue of diabetes mellitus, so that more studies on the quality of life in patients with type $2 \mathrm{DM}$ are needed. Improving the quality of life is one of the goals of DM treatment management therapy.

\section{SUBJECTS AND METHOD}

\section{Study Design}

This was a cross-sectional study carried out at Dr. Moewardi, Surakarta, from February to March 2020.

\section{Population dan Sample}

The study population was patients with type 2 DM. A sample of 120 patients with type 2 DM aged $>18$ years was selected by simple random sampling.

\section{Study Variables}

The dependent variable was the quality of life. The independent variables were selfcare, family support, peer support, length of disease, sleep quality, body mass index, income, education, age, and complications.

\section{Operational Definition of Variables}

Self-care was a self-care activity carried out by patients with type $2 \mathrm{DM}$ to control their diabetes, including diet, physical exercise, blood sugar monitoring, medication, and foot care for seven days. The data were measured by SDSCA questionnaire (Toobert et al., 2000). The measurement scale was continous and transformed into dichotomous, coded $o=$ poor $(<43.36) ; 1=\operatorname{good}(\geq 43.36)$.

Family support was the support provided by members who had wedlock or in-blood relationships in the form of emotional support, information support, instrumental support, and appreciation support. The data were measured by questionnaire. The measurement scale was continous and transformed into dichotomous, coded $\mathrm{o}=$ weak $(<41.99)$; $1=$ strong $(\geq 41.99)$.

Peer support was the support provided by friends who had the same age, experience, and interests in the form of emotional support, information support, financial support, and appreciation support. The data were measured by questionnaire. The measurement scale was continous and transformed into dichotomous, coded $\mathrm{o}=$ weak $(<48.66)$; $1=\operatorname{strong}(\geq 48.66)$. 
Income was the amount of income earned every month based on the city minimum wage, which was used to meet collective and individual needs. The data were measured by questionnaire. The measurement scale was continous and transformed into dichotomous, coded $\mathrm{o}=(<\operatorname{Rp} 1,900,000)$ and $1=\geq$ Rp 1,900,000

Sleep quality was a measure of the good and bad of a person's sleep habits during the last month. The data were masured by PSQI questionnaire (Buysse et al., 1998). The data were measured by questionnaire. The measurement scale was continous and transformed into dichotomous, coded $\mathrm{O}=$ poor $(<3) ; 1=$ $\operatorname{good}(\geq 3)$.

The time period of diagnosis was the time period when the respondent suffers from type 2 diabetes mellitus. The data were measured by questionnaire. The measurement scale was continous and transformed into dichotomous, coded $0=<6$ years; $1=\geq 6$ years.

Body mass index was the result of dividing body weight and height squared in type $2 \mathrm{DM}$ patients. The data were measured by questionnaire. The measurement scale was continous and transformed into dichotomous, coded $\mathrm{O}=$ normal $(18.50-22.99) ; 1=$ malnutrition $(\geq 23.00$ or $<18.50$ ).

Education was the last formal level of education for patients with type $2 \mathrm{DM}$. The data were measured by questionnaire. The measurement scale was categorical, coded $\mathrm{O}=(<\mathrm{Se}-$ nior High Shcool); 1 = ( $\geq$ Senior High School). Age was the patient's age from the time of birth to the time the study was conducted. The measuring instrument used was a questionnaire. The data were measured by questionnaire. The measurement scale was continous and transformed into dichotomous, coded $\mathrm{o}=(<55$ years $) ; 1=(\geq 55$ years $)$.

Quality of life was a subjective view of type 2 DM patients on perceived satisfaction related to physical abilities, social relation- ships, and the environment after diagnosis and treatment. The data were measured by DQLCTQ questionnaire (Shen and Kotsanos, 1999). The measurement scale was continous and transformed into dichotomous, coded $\mathrm{o}=$ poor $(<195 \cdot 33)$; $1=\operatorname{good}(\geq 195 \cdot 33)$.

\section{Data Analysis}

Statistical analysis used the Stata 13 program. In univariate analysis, sample characteristics with continuous data would be displayed as parameters $\mathrm{n}$, mean, standard deviation, minimum, and maximum. Categorical data were displayed in $\mathrm{n}$ and percent. The bivariate analysis used the chi-square test conducted on each variable at the individual level to see its effect on the quality of life in patients with type $2 \mathrm{DM}$. Multivariate analysis used a path analysis model (Path Analysis). Path analysis was used to determine the magnitude of the influence of another variable, either directly or indirectly.

The magnitude of the influence of the independent variable on the dependent variable was seen from the value of the path coefficient. The path coefficient had no units, so it could be concluded that the greater the path coefficient, the greater the influence of these variables (Murti, 2018).

\section{Research Ethic}

This research was conducted based on research ethics, namely informed consent, anonymity, confidentiality, and ethical worthiness. This study's ethical permission was obtained from the Health Research Ethics Commission of Dr. Moewardi, Surakarta, Indonesia, No. 114 / I / HREC / 2020.

\section{RESULTS}

\section{A. Sample Characteristics}

The study was conducted on 120 subjects who were in Dr. Moewardi Surakarta Regional Public Hospital. The sample characteristics for continuous variables and dichotomies were shown in Table 1 and Table 2, respectively. 
Marlina et al./ Path Analysis on Factors Affecting the Quality of Life

Table 1. Characteristic of sample (continous data)

\begin{tabular}{lccccc}
\hline \multicolumn{1}{c}{ Variable } & n & Mean & SD & Min. & Max. \\
\hline Age (years) & 120 & 51.55 & 7.547998 & 40 & 72 \\
Income (rupiahs) & 120 & $1,562,083$ & 715758.9 & 500,000 & $4,000,000$ \\
Family support & 120 & 41.99 & 10.71 & 20 & 50 \\
Peer support & 120 & 48.66 & 8.10 & 30 & 54 \\
Self-care & 120 & 43.36 & 12.49 & 23 & 60 \\
Sleep quality & 120 & 3.09 & 1.974611 & 1 & 8 \\
Time period of diagnosis (year) & 120 & 4.4 & 2.06 & 1 & 10 \\
Body mass index & 120 & 21.29 & 2.54 & 20 & 25.07 \\
Quality of life & 120 & 195.33 & 25.28 & 140 & 216 \\
\hline
\end{tabular}

Table 2. Characteristic of sample (continuous data)

\begin{tabular}{|c|c|c|c|}
\hline Variable & Criteria & Frequency (n) & Percentage (\%) \\
\hline \multirow[t]{2}{*}{ Sex } & Male & 85 & 70.83 \\
\hline & Female & 35 & 29.17 \\
\hline \multirow[t]{2}{*}{ Age (year) } & $<55$ & 77 & 64.17 \\
\hline & $\geq 55$ & 43 & 35.83 \\
\hline \multirow[t]{2}{*}{ Income (rupiahs) } & $<1,900,000$ & 63 & $53 \cdot 50$ \\
\hline & $\geq 1,900,000$ & 57 & $47 \cdot 50$ \\
\hline \multirow[t]{2}{*}{ Education } & $<$ Senior High School & 29 & 24.17 \\
\hline & $\geq$ Senior High School & 91 & 75.83 \\
\hline \multirow[t]{2}{*}{ Family support } & Weak & 31 & 25.83 \\
\hline & Strong & 89 & 74.17 \\
\hline \multirow[t]{2}{*}{ Peer support } & Weak & 29 & 24.71 \\
\hline & Strong & 91 & 75.83 \\
\hline \multirow[t]{2}{*}{ Self-care } & Poor & 19 & 15.83 \\
\hline & Good & 101 & 84.17 \\
\hline \multirow[t]{2}{*}{ Sleep quality } & Poor & 21 & $17 \cdot 50$ \\
\hline & Good & 99 & 82.50 \\
\hline \multirow[t]{2}{*}{ Time period of diagnosis (year) } & $<6$ & 93 & $77 \cdot 50$ \\
\hline & $\geq 6$ & 27 & 22.50 \\
\hline \multirow[t]{2}{*}{ Body mass index } & normal & 86 & 71.67 \\
\hline & Malnutrition & 34 & 28.33 \\
\hline \multirow[t]{2}{*}{ Quality of life } & Poor & 23 & 19.17 \\
\hline & Good & 97 & 80.83 \\
\hline
\end{tabular}

The mean age of the subjects of the study was 51.55 years, the mean value of the subject's income was IDR $1,562,083$, the mean value of family support for the study subjects was 41.99, the mean value of peer support for study subjects was 48.66, the mean value of self-care for study subjects was 43.36, the mean value The sleep quality of the study subjects was 3.09, the mean value of the time period of diagnosis of the study subjects was 4.4, the mean value of the body mass index of the study subjects was 21.29, and the average value of the quality of life of the study subjects was 195.33.

\section{B. Univariate analysis}

Table 2 shows that as many as 85 study subjects (70.83\%) were male. Patients with age $<55$ years were 77 study subjects (64.17\%). Patients who had low income $(<$ Rp. $1,900,-$ ooo) were 63 study subjects (53.50\%). Pa- 
tients with high education ( $\geq$ Senior High School) were 91 study subjects (75.83\%). Patients with strong family support were 89 subjects $(74.17 \%)$.

Patients with strong peer support were 91 (75.83\%), had good self-care (84.17\%), had good sleep quality (82.50\%), length of disease since diagnosis $<6$ years $(77.50 \%)$, normal body mass index (71.67\%), and had good quality of life (80.83\%).

\section{The result of bivariate analysis}

Table 3 shows high family income $(\mathrm{OR}=8.37$; $\mathrm{p}<$ 0.001), $\geq$ Senior High School $(\mathrm{OR}=11.11$; $\mathrm{p}<0.001)$, strong family support $(\mathrm{OR}=5.70$; $\mathrm{p}<0.001)$, strong peer support $(\mathrm{OR}=8.50$; $\mathrm{p}$ $<0.010)$, good self-care $(\mathrm{OR}=7.52 ; \mathrm{p}$ $<0.001)$, and good sleep quality $(\mathrm{OR}=7.97 ; \mathrm{p}$ $<0.001$ ) improve the quality of life in patients with type $2 \mathrm{DM}$. There was an effect between family income, education, family support, peer support, self-care, and sleep quality on quality of life in type $2 \mathrm{DM}$ patients.

Female $(\mathrm{OR}=0.08 ; \mathrm{p}<0.001)$, age $(\mathrm{OR}=$ $0.07 ; \mathrm{p}<0.001)$, time period of diagnosis $\geq 6$ years $(\mathrm{OR}=0.16 ; \mathrm{p}<0.001)$, and malnutrition $(\mathrm{OR}=0.16 ; \mathrm{p}<0.001)$ decreased quality of life in patients with type $2 \mathrm{DM}$.

Table 3. Bivariate analysis of factors affecting the quality of life of type 2 DM patients

\begin{tabular}{|c|c|c|c|c|c|}
\hline \multirow{2}{*}{ Independent Variable } & \multicolumn{2}{|c|}{ Quality of life } & \multirow{2}{*}{$\begin{array}{l}\text { Total } \\
\text { n (\%) }\end{array}$} & \multirow{2}{*}{$\mathbf{O R}$} & \multirow{2}{*}{$\mathbf{p}$} \\
\hline & $\begin{array}{l}\text { Poor } \\
\text { n (\%) }\end{array}$ & $\begin{array}{l}\text { Good } \\
\text { n (\%) }\end{array}$ & & & \\
\hline \multicolumn{6}{|l|}{ Gender } \\
\hline Male & $6(7.06)$ & $79(92.94)$ & $85(100)$ & 0.08 & $<0.001$ \\
\hline Female & $17(48.57)$ & $18(51.43)$ & $35(100)$ & & \\
\hline \multicolumn{6}{|l|}{ Age (year) } \\
\hline$<55$ & $4(5.19)$ & $73(94.81)$ & $77(100)$ & 0.07 & $<0.001$ \\
\hline$\geq 55$ & $19(44.19)$ & $24(55.81)$ & $43(100)$ & & \\
\hline \multicolumn{6}{|l|}{ Income (rupiahs) } \\
\hline$<1,900,000$ & $20(31.75)$ & $43(68.25)$ & $63(100)$ & 8.37 & $<0.001$ \\
\hline$\geq 1,900,000$ & $3(5.26)$ & $54(94.74)$ & $54(100)$ & & \\
\hline \multicolumn{6}{|l|}{ Education } \\
\hline$<$ Senior High School & $15(51.72)$ & $14(48.28)$ & $29(100)$ & 11.11 & $<0.001$ \\
\hline$\geq$ Senior High School & $8(8.79)$ & $83(91.21)$ & $91(100)$ & & \\
\hline \multicolumn{6}{|l|}{ Family support } \\
\hline Weak & $13(41.94)$ & $18(58.06)$ & $31(100)$ & $5 \cdot 70$ & $<0.001$ \\
\hline Strong & $10(11.24$ & $79(88.76)$ & $89(100)$ & & \\
\hline \multicolumn{6}{|l|}{ Peer support } \\
\hline Weak & $14(48.28)$ & $15(51.72)$ & $29(100)$ & 8.50 & $<0.001$ \\
\hline Strong & $9(9.89)$ & $82(90.11)$ & $91(100)$ & & \\
\hline \multicolumn{6}{|l|}{ Self-care } \\
\hline Poor & $10(52.63)$ & $9(47.37)$ & $19(100)$ & $7 \cdot 52$ & $<0.001$ \\
\hline Good & $13(12.87)$ & $88(87.13)$ & $101(100)$ & & \\
\hline \multicolumn{6}{|l|}{ Sleep quality } \\
\hline Poor & $11(52.38)$ & $10(47.62)$ & $21(100)$ & $7 \cdot 97$ & $<0.001$ \\
\hline Good & $12(12.12)$ & $87(87.88)$ & $99(100)$ & & \\
\hline \multicolumn{6}{|l|}{$\begin{array}{l}\text { Time period of } \\
\text { diagnosis (year) }\end{array}$} \\
\hline$<6$ years & $11(11.83)$ & $82(88.17)$ & $93(100)$ & 0.16 & $<0.001$ \\
\hline$\geq 6$ years & $12(44.44)$ & $15(55.56)$ & $27(100)$ & & \\
\hline \multicolumn{6}{|l|}{ Body mass index } \\
\hline Normal & $9(10.47)$ & $77(89.53)$ & $86(100)$ & 0.16 & $<0.001$ \\
\hline Malnutrition & $14(41.18)$ & $20(58.82)$ & $34(100)$ & & \\
\hline
\end{tabular}




\section{D.The result of multivariate analysis}

Table 4 shows that patients with type 2 DM with strong family support had probability (logodd) of having good quality of life 3.07 units higher than patients with weak family support.

Patients with strong peer support had a probability (logodd) of good quality of life 3.43 units higher than patients with weak peer support.

Patients with good self-care had possibility (logodd) of good quality of life 2.66 units higher than patients with poor self-care.

There was a direct effect of self-care on the quality of life of Type 2 DM patients.
Good self-care could improve the quality of life in patients with type $2 \mathrm{DM}$.

Patients with a length of disease $<6$ years had logodd of good quality of life 2.90 units lower than those with length of disease $\geq 6$ years.

Patients with a normal body mass index were 2.54 units less likely (logodd) to have good quality of life than those with malnourished body mass index.

Patients with $\geq$ Senior High School education had logodd of good quality of life 2.46 units higher than those with education $<$ Senior High School.

Table 4. Path analysis of factors affecting quality of life in patients with type 2 DM

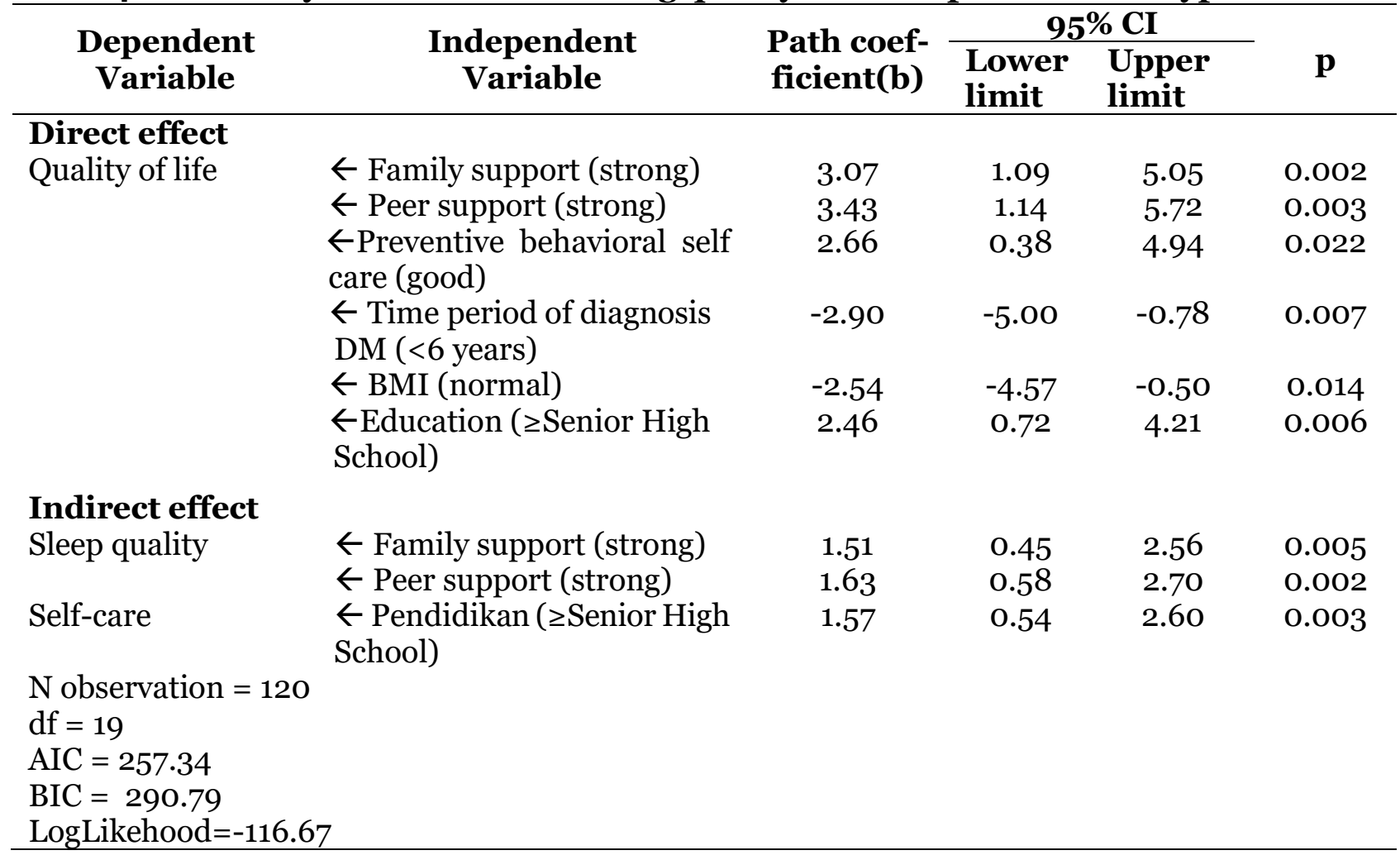

\section{DISCUSSION}

1. The effect of education on the quality of life in patients with type 2 DM The path analysis found that education had a direct effect on the quality of life of patients with type 2 diabetes $(b=2.46 ; 95 \% \mathrm{CI}=0.72$ to $4.21 ; \mathrm{p}=0.006)$. Patients with type $2 \mathrm{DM}$ with education level $\geq$ Senior High School have a probability of having a good quality of life 2.46 units higher than patients with education level < Senior High School.

In patients with type $2 \mathrm{DM}$ with elementary and secondary school education 
levels, understanding information about DM was rather slow. This situation affects their quality of life because information or knowledge about DM is not fully obtained. According to Flatz et al. (2015), type 2 DM patients with high levels of education have increased self-care.

\section{The effect of family support on the quality of life in patients with type 2 DM}

In the path analysis, it was found that family support had a direct effect on patients' quality of life with type $2 \mathrm{DM}(\mathrm{b}=3.07 ; 95 \%$ $\mathrm{CI}=1.09$ to $5.05 ; \mathrm{p}=0.002$. Patients with type 2 DM with strong family support had a 3.07 units higher probability of having a good quality of life than patients without family support.

This study's results are in line with the results of a study conducted by Azmoude et al. (2016), which stated that patients with type 2 diabetes who had active family support showed a significant difference in the quality of life of patients. The existence of family support can provide compliance with the wishes of type 2 DM patients in managing disease treatment.

\section{The effect of peer support on the quality of life in patients with type 2 DM}

In the path analysis, it was found that peer support had a direct effect on the quality of life of type $2 \mathrm{DM}$ patients $(\mathrm{b}=3.43$; $95 \% \mathrm{CI}=$ 1.14 to $5.72 ; p=0.003$. Patients with type 2 DM with strong peer support had the 3.43 units higher possibility to have a good quality of life than patients who did not have peer support.

This is in line with the results of a study conducted by Sreedevi et al. (2020) that the group of people with type 2 diabetes who has peer support has a significant difference in the quality of life. Peer support is useful in terms of self-management assistance, can influence DM sufferers in complying with dietary rules, sports activities, and aims to control complications of other diseases.

\section{The effect of self-care on the quality of life in patients with type 2 DM}

In the path analysis, it was found that selfcare had a direct effect on patients' quality of life with type $2 \mathrm{DM}(\mathrm{b}=2.66 ; 95 \% \mathrm{CI}=0.38$ to $4.94 ; \mathrm{p}=0.022$. Patients with type $2 \mathrm{DM}$ with good self-care had a 2.66 units higher probability of having a good quality of life than patients with poor self-care.

This is in line with a study conducted by Hall et al., (2009), which stated that the quality of life for people with Type $2 \mathrm{DM}$ is affected by daily self-care. According to Gita et al., (2020), exercise or physical activity is very important; it can increase insulin resistance so that insulin becomes more effective in transporting glucose.

\section{The effect of the time period of diag- nosis on the quality of life in pa- tients with type 2 DM}

The path analysis found that the time period of diagnosis had a direct effect on the quality of life of type $2 \mathrm{DM}$ patients $(\mathrm{b}=-2.90 ; 95 \%$ $\mathrm{CI}=-5.00$ to $-0.78 \mathrm{p}=0.007$. Type $2 \mathrm{DM}$ patients with a diagnosis time period $<6$ years had the possibility of quality 2.90 units lower than patients whose diagnosis time period was $\geq$ six years.

A study conducted by Anindyati (2013) in Budiarti (2018) found that the function of pancreatic beta cells in patients with old diabetes has been damaged. The results of a study conducted by Lima et al. (2018) also stated that T2DM patients with a long diagnosis duration, such as more than ten years, their body health function decreases faster so that the quality of life they get is lower.

\section{Effect of BMI on the quality of life in patients type 2 DM.}

In the path analysis, it was found that BMI directly affected the quality of life in patients with type $2 \mathrm{DM}(\mathrm{b}=-2.54 ; 95 \% \mathrm{CI}=-4.57$ to $-0.50 \mathrm{p}=0.014$. Patients with type $2 \mathrm{DM}$ 
with normal status BMI had the possibility of having good quality of life 2.54 units lower than patients who had BMI with malnutrition status.

This is in line with a study conducted by Zhu et al. (2015), which stated that there is a significant difference between BMI and quality of life in patients with type $2 \mathrm{DM}$. People who have a BMI with the overweight category have a lower quality of life score than people who have a normal BMI (Rambod et al., 2020).

\section{The effect of family support on the sleep quality in patients with type 2 DM}

There was an indirect effect on the quality of life in patients with type $2 \mathrm{DM}$ through family support on sleep quality. Patients with strong family support were more likely (logodd) to get good sleep quality 1.51 units higher than patients who had weak family support $(b=1.51 ; 95 \% \mathrm{CI}=0.45$ to $2.56 ; \mathrm{p}=$ 0.005).

Good quality sleep also has an effect on improving the quality of life for people with diabetes. This is in accordance with a study conducted by Morin et al., (2003), which stated that individuals who can rely on family members to help them cope with stressful events and situations are likely to limit the effects of stressors that are believed to improve sleep quality.

\section{The effect of peer support on sleep quality in patients with type 2 DM}

There was an indirect effect on the quality of life in patients with type $2 \mathrm{DM}$ through peer support on sleep quality. Patients with strong peer support were more likely (logodd) to get good sleep quality 1.63 units higher than patients who had weak peer support $(b=1.63$; $95 \% \mathrm{CI}=0.58$ to $2.70 ; \mathrm{p}=0.002$ ).

This is in line with a study conducted by Stafford et al. (2017), which stated that social support or peer support is associated with an increased risk of greater sleep disorders. The existence of social support or peer support can give a feeling of being valued and even respected.

\section{Effect of education on self-care in patients with type 2 DM}

There was an indirect effect on the quality of life in patients with type $2 \mathrm{DM}$ through the level of education on preventive behavior self-care. Patients with education level $\geq$ Senior High School had a (logodd) probability of getting high preventive behavior selfcare 1.57 units higher than patients who had low preventive behavior self-care $(b=1.57$; $95 \% \mathrm{CI}=0.54$ to $2.60 ; \mathrm{p}=0.003$ ).

Someone with a high level of education, if they have a chronic disease, they are able to increase understanding and knowledge related to the disease they suffer and its treatment (Gonzalez et al., 2005; Boyde et al., 2011; Gonzalez et al., 2014). Knowledge related to Type $2 \mathrm{DM}$ can make patients have a positive influence on self-care.

\section{AUTHOR CONTRIBUTION}

Devi Marlina was the main researcher. As the main researcher, Devi Marlina had a role in proposing the ideas of the study, coordinating at all stages of the study, and completing the research paper. Didik Gunawan Tamtomo had a role in developing ideas, study designs, and study hypotheses. RB. Soemanto had a role in the formulation of study methods and discussion of outcome studies.

\section{CONFLICT OF INTEREST}

The abstract of this study was presented for an oral presentation at the 7 th International Conference of Public Health.

\section{FUNDING AND SPONSORSHIP}

The source of funds in this study used personal funds from the main researcher.

\section{ACKNOWLEDGEMENT}


The author would like to express his gratitude to the DR. Moewardi Regional Public Hospital, who helped this study be carried out. The author also would like to express his gratitude to all patients who had been willing and cooperative to be the subject of study.

\section{REFERENCE}

Azmoude E, Tafazoli M, Parnan A (2016). Assessment of family functioning and its relationship to quality of life in diabetic and non-diabetic women. Int. J. Caring Sci, 5(3): 231-239. http://doi.org/10.15171/jcs.2016.025.

Boyde M, Turner C, Thompson DR, Steward $\mathrm{R}$ (2011). Educational interventions for patients with heart failure: A systematic review of randomized controlled trials. J Cardiovasc Nurs, 26(4): E27-35. http://doi.org/10.1097/JCN.obo13e31 $81 \mathrm{ee} 5 \mathrm{fb} 2$.

Budiarti E, Tamtomo DG, Adriani RB (2018). Path analysis on the biopsychosocial determinants of type 2 diabetes mellitus and depression at Dr. Moewardi Hospital, Surakarta. J Epidemiol Public Health, 3(1): 1-14. https://doi.org/10.26911/jepublichealth.2018.03.01.01.

Buysse DJ, Reynolds CF, Monk TH, Berman SR, Kupfer DJ (1998). The Pittsburgh sleep quality index: A new instrument for psychiatric practice and research. Psychiatry Res, 28(2): 193-213. https://doi.org/10.1016/0165-1781(89)90047-4.

Dinas Kesehatan Kota Surakarta (2017). Profil kesehatan kota Surakarta tahun 2017. DKK Surakarta. Surakarta.

Flatz A, Cassilas A, Stringhini S, Zuercher E, Burnand B, Peytreman I (2015). Association between education and quality of diabetes care in Switzerland. Int $\mathrm{J}$ Gen Med, 8(1), 87-92. http://doi.org/10.2147/IJGM.S77139.
Gonzalez B, Lupon J, Domingo MD, Cano L, Cabanes R, Antonio MD, Arenas M, Crespo E, Rodrigues M, Bayes-genis A (2014). Educational level and self-care behavior in patients with heart failure before and after nurse educational intervention. Eur J Cardiovasc Nurs, 13(5): 459-465. http://doi.org/ 10.1177/1474515113510810.

González B, Lupon J, Herreros J, Urrutia A, Altimir S, Coll R, Prats M, Valle V (2005). Patient's education by nurse: what we really do achieve?. Eur J Cardiovasc Nurs, 4(2): 107-111. http://doi.org/10.1016/j.ejcnurse.2005.03.006.

Gillani SW, Ansari IA, Zaghloul HA, Sulaiman SAS, Rathore HA, Baig MR, Abdul MI, Althagfan S (2018). Predictors of health related quality of life among patients with type II diabetes melitus who are insulin users A multidimensional model. Curr Ther Res Clin E, 90(1): 536o. https://doi.org/10.1016/j.curtheres.2019.04.001.

Gita APA, Qadrijati I, Murti B (2020). Multilevel analysis: villages do not have ecological effect on the risk of diabetes mellitus type 2 in Surakarta, Central Java. J Epidemiol Public Healt, 05(11): 106-118. https://doi.org/10.26911/jepublichealth.2020.05.01.11.

Hall PA, Rodin GM, Vallis TM, Perkins BA (2009). The consequences of anxious temperament for disease detection, self-management behavior, and quality of life in type 2 diabetes mellitus. J Psychosom Res, 67(4): 297-305. http://doi.org/10.1016/j.jpsychores.2009.05.015 .

International Diabetes Federation (2017). IDF diabetes atlas 8th edition. Retrieved from https://diabetesatlas.org/resources/2017-atlas.html. Surakarta.

Kementrian Kesehatan RI (2013). Riset Kesehatan Dasar. Jakarta. 
Lima LR, Funghetto SS, Volpe CRG, Santos WS, Funez MI, Stival MM (2018). Quality of life and time since diagnosis of diabetes mellitus among the elderly. Rev Bras Geriatr Gerontol, 21(2): 176185. https://doi.org/10.1590/1981-22562018021.170187.

Lou P, Qin Y, Zhang P, Chen P, Zhang L, Chang G, Li T, Qiao C, Zhang N (2015). Association of sleep quality and quality of life in type 2 diabetes mellitus: A cross-sectional study in China. Diabetes Res Clin Pract, (107)1, 69-76. http://doi.org/10.1016/j.diabres.2014.09.060

Murti B (2018). Prinsip dan metode riset epidemiologi. Surakarta: Program Studi Ilmu Kesehatan Masyarakat Universitas Sebelas Maret.

Morin CM , Rodrigue S, Ivers H (2003). Role of stress, arousal, and coping skills in primary insomnia. Psychosom Med, 65(2): 259-67. http://doi.org/10.1097/01.psy.0000030391.09558.a3

Rambod M, Ghodsbin M, Moradi A (2020). The association between body mass index and comorbidity, quality of life, and cognitive function in the elderly population. Int J Community Based Nurs Midwifery, 8(1): 45-54. http://doi.org/10.30476/IJCBNM.2019.81677.0.

Shen W, Kotsanos J (1999). Diabetes Quality of Life Clinical Trial Questionnaire (DQLCTQ). Retrieved from https://eprovide.mapi-trust.org/instruments/dia- betes-quality-of-life-clinical-trial-questionnaire.

Sreedevi S, Unikrishnan AG, Karimassery SR, Deepak KS (2020). The effect of yoga and peer support interventions on the quality of life of women with diabetes: results of a randomized controlled trial. Indian $\mathrm{J}$ Endocrinol Metab, 21(4): 524-530. http:// doi.org/10.4103/ijem.IJEM_28_17.

Stafford M, Bendayan R, Tymoszuk U, Kuh D (2017). Social support from the closest person and sleep quality in later life evidence from a british birth cohort study. J Psychosom Res, 1(1): 1-9. Https://doi.org/10.1016/j.jpsychores.2017.04.014.

Toobert DJ, Hampson SE, Glasgow RE (2000). Summary of diabetes self-care activities (SDSCA). Retrieved from https://eprovide.mapi-trust.org/instruments/summary-of-diabetes-self-careactivities.

Zhu Y, Wang Q, Pang G, Lin L, Origasa H, Wang Y, Die J, Shi M, Fan C, Shi H (2015). Association between body mass index and health-related quality of life: the "obesity paradox" in 21,218 adults of the Chinese general population. Plos one, 10(6): 1-13. http://doi.org/10.1371/journal.pone.0130613. 